Center for the Advancement of Sustainability Innovations (CASI)

\title{
Relevance of Emerging Ecosystem Service Science and Policy to the United States Department of Defense
}

Elizabeth Keysar

September 2011
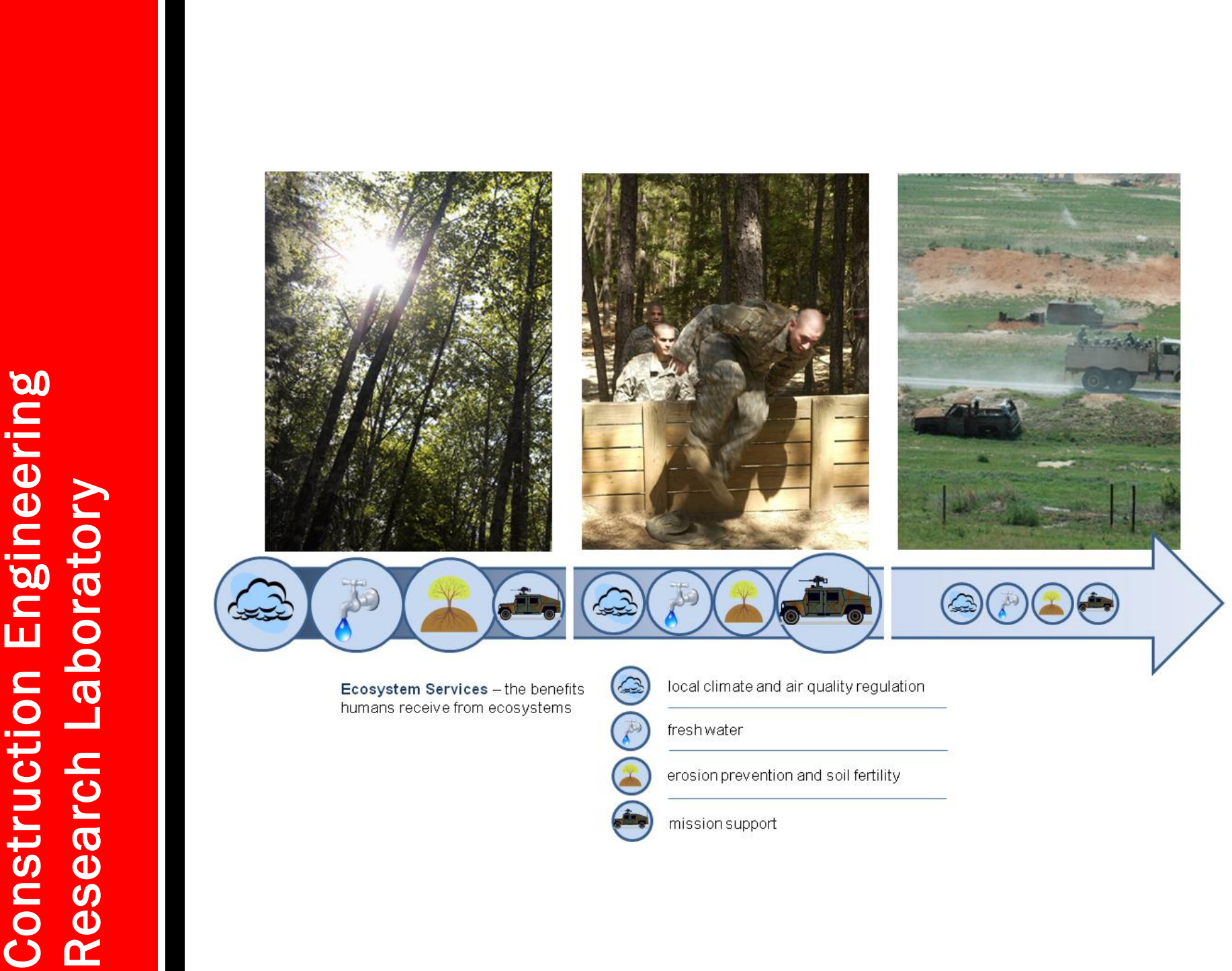

US Army Corps of Engineers $s_{\circledast}$

Engineer Research and Development Center 



\section{Relevance of Emerging Ecosystem Service Science and Policy to the United States Department of Defense}

Elizabeth Keysar

Concurrent Technologies Corporation 100 CTC Drive

Johnstown, PA 15904

Final report

Approved for public release; distribution is unlimited.

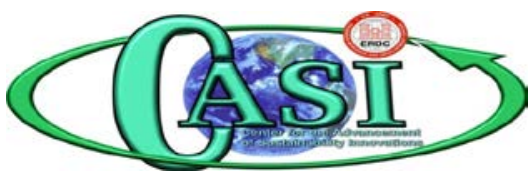

https://casi.erdc.usace.army.mil/

Prepared for Army Environmental Policy Institute

1550 Crystal Drive

Arlington, VA 22202

Under Work Unit 9J2017

Monitored by Construction Engineering Research Laboratory

US Army Engineer Research and Development Center

2902 Newmark Drive

PO Box 9005

Champaign, IL 61826-9005 


\section{Abstract}

The concept of ecosystem services has been increasingly applied to ensure the benefits from ecosystems are incorporated into decision making. This idea supports sustainability goals by linking natural capital with financial capital. The concept of ecosystem services can assist the United States Department of Defense (DoD) in making natural resources decisions today for improved long-term outcomes. The concept also has strategic planning implications because the military's role continues to evolve along with international security concerns. This report summarizes the latest literature on ecosystem services in science and policy, to describe ways in which emerging applications of this concept may impact military planning and policy. The report's four sections provide an overview of the concept of ecosystem services and its recent adoption by major science and policy stakeholders; reviews of some recent applications of the concept; links of these applications to military activities; and recommendations and conclusions. The study concludes the DoD needs to (1) successfully engage with stakeholders on conservation issues; (2) use new tools and data sources in decision making; and (3) prepare for new regulatory requirements. The DoD should move forward with institutionalizing the concept of ecosystem services through additional research, engagement, training, and outreach.

DISCLAIMER: The contents of this report are not to be used for advertising, publication, or promotional purposes. Citation of trade names does not constitute an official endorsement or approval of the use of such commercial products. All product names and trademarks cited are the property of their respective owners. The findings of this report are not to be construed as an official Department of the Army position unless so designated by other authorized documents. 


\section{Table of Contents}
Abstract ii
List of Figures and Tables...........................................................................................................

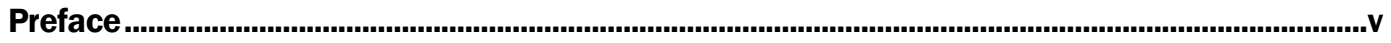

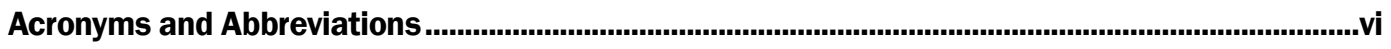
1 Introduction .................................................................................................................................. 1

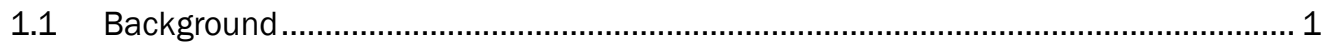

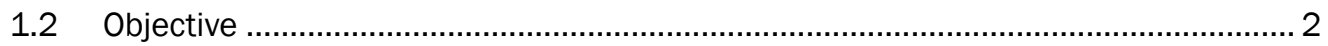

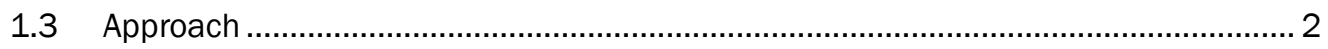

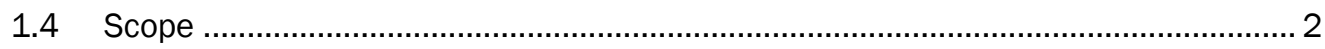

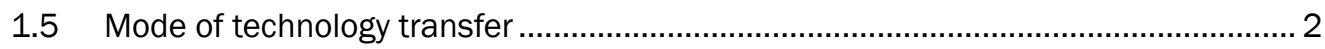

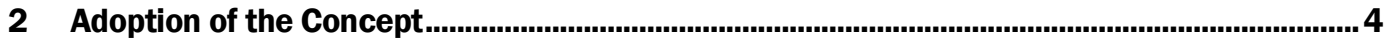

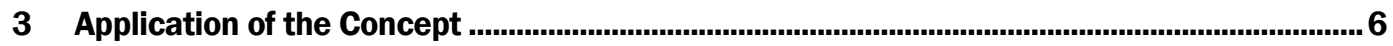

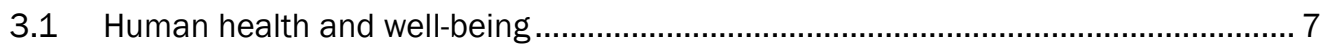

3.2 Natural resource conservation ....................................................................... 9

3.3 Natural resource management....................................................................... 10

3.4 Environmental and ecological economics...................................................... 11

3.5 Environmental impact assessment and mitigation .........................................12

4 Implications for the Department of Defense............................................................................14

4.1 Strategic planning in support of contingency operations ........................................ 15

4.2 Natural resource management............................................................................... 16

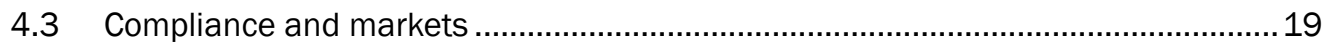

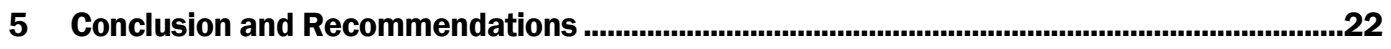

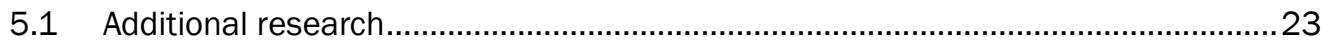

5.1.1 Measurement and analytical tools................................................................. 23

5.1.2 Review of existing reporting and decision-making tools..................................... 23

5.1.3 Review of existing management practices........................................................... 24

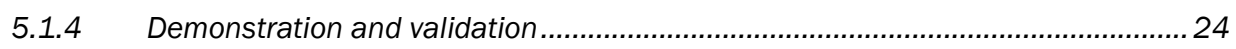

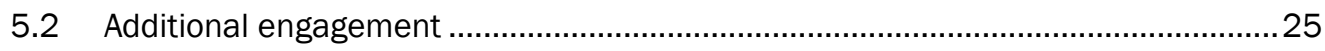

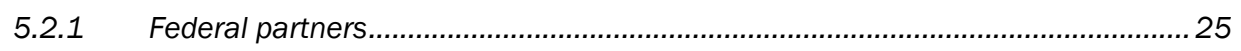

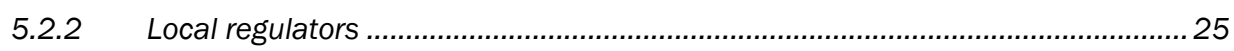

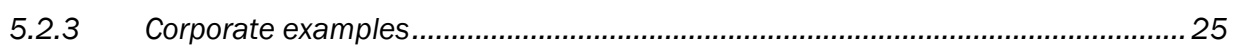

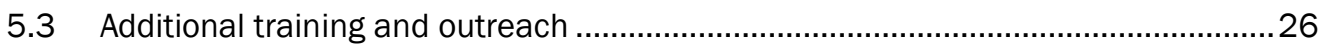

5.3.1 Environmental and planning professionals....................................................... 26

5.3.2 Training land management professionals ....................................................... 26

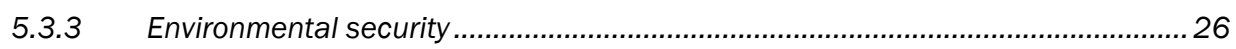

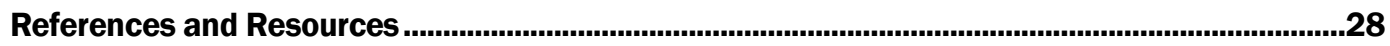




\section{List of Figures and Tables}

\section{Figures}

Figure 1. Millennium ecosystem assessment classification scheme (MA 2005)...............................

Figure 2. Application of the ecosystem services concept........................................................................

Figure 3. Changes in ecosystem service provision with changes in land use. ...................................18

\section{Tables}

Table 1. Emerging areas of ecosystem services science and policy.................................................15

Table 2. Examples of ecosystem services relevant to the DoD from off-post land uses....................19 


\section{Preface}

This study was conducted for the Army Environmental Institute (AEPI) under Work Unit 9J 2017. The AEPI technical monitors were Mr. J ohn Fittipaldi and Mr. Michael Cain.

The work was performed by Concurrent Technologies Corporation (CTC) under the Broad Agency Announcement Contract No. W9132T-10-C-0045, "Emerging Ecosystem Services Science and Policy," under supervision of the US Army Engineer Research and Development Center - Construction Engineering Research Laboratory (ERDC-CERL). The ERDC-CERL project manager was Dr. Tim Hayden of the Ecological Process Branch (CEERD-CN-N). Mr. William Goran was Director of the Center for the Advancement of Sustainability Innovations (CASI) and Technical Director for Strategic Planning and Technical Program Development (CEERD-CVT). Ms. Michelle Hanson was Associate Director of CASI. At the time of publication, Mr. William Meyer was Chief, CEERD-CN-N, and Dr. J ohn Bandy was Chief, CEERD-CN. The Deputy Director of ERDC-CERL was Dr. Kirankumar Topudurti and the Director was Dr. Ilker Adiguzel.

COL Kevin J. Wilson was the Commander and Executive Director of ERDC, and Dr. J effery P. Holland was the Director. 


\section{Acronyms and Abbreviations}

\begin{tabular}{|c|c|}
\hline Term & Spellout \\
\hline ACUB & Army Compatible Use Buffer \\
\hline AFRICOM & African Command \\
\hline AICUZ & Air Installation Compatible Use Zones \\
\hline AEPI & Army Environmental Policy Institute \\
\hline CERCLA & Comprehensive Environmental Response, Compensation, and Liability Act \\
\hline CEQ & Council on Environmental Quality \\
\hline CERL & Construction Engineering Research Laboratory \\
\hline CRP & Conservation Reserve Program \\
\hline CWA & Clean Water Act \\
\hline DoD & Department of Defense \\
\hline EIA & environmental impact assessments \\
\hline ERDC & Engineer Research and Development Center \\
\hline ESA & Endangered Species Act \\
\hline ESTCP & Environmental Security Technology Certification Program \\
\hline INRMP & Integrated Natural Resource Management Plan \\
\hline ISR & Installation Status Report \\
\hline ITAM & Integrated Training Area Management \\
\hline MA & Millennium Ecosystem Assessment \\
\hline MDGs & Millennium Development Goals \\
\hline MOU & Memorandum of Understanding \\
\hline NEPA & National Environmental Policy Act \\
\hline NESP & National Ecosystem Services Partnership \\
\hline $\mathrm{NI}$ & natural infrastructure \\
\hline NIM & Natural Infrastructure Program \\
\hline NRDA & Natural Resource Damage Assessments \\
\hline ODUSD I\&E & Office of the Secretary of Defense, Installations and Environment \\
\hline OEM & Office of Environmental Markets \\
\hline OPA & Oil Pollution Act \\
\hline PES & payment for ecosystem service \\
\hline QDR & Quadrennial Defense Review \\
\hline RTLP & Range and Training Land Program \\
\hline SRP & Sustainable Range Program \\
\hline SSTR & stability, security, transition and reconstruction \\
\hline US & United States \\
\hline USACE & United States Army Corps of Engineers \\
\hline USDA & United States Department of Agriculture \\
\hline USEPA & United States Environmental Protection Agency \\
\hline WRI & World Resource Institute \\
\hline
\end{tabular}




\section{Introduction}

\subsection{Background}

The emergence of the sustainability paradigm was driven by a need to bring environmental concerns into economic decision making. There was a need to understand the fundamental links between human well-being and the health of the ecosystems that underlie all economic activity. More recently, the concept of ecosystem services has been increasingly applied to ensure the benefits that people receive from ecosystems are incorporated into decision making. The idea supports achievement of sustainability goals and objectives by linking natural capital with financial capital. Making this connection continues to be a challenge, as many decision makers continue to view environmental concerns as compromising economic gains or mission accomplishment. The concept of ecosystem services provides a framework to overcome this ongoing disconnect. It has proven to be a useful construct for interdisciplinary conversations, and is rapidly being adopted by the governmental and nongovernmental communities as the need to make informed natural resource management decisions becomes more and more of a critical concern.

The concept of ecosystem services can assist the US Department of Defense (DoD) in making natural resources decisions today for improved outcomes in the long term. It also has implications for strategic planning as the role of the military continues to evolve along with international security concerns. There are also potential impacts for installation land managers as the concept is incorporated into regulatory approaches such as environmental impact assessment and compensatory mitigation. Overall, the concept of ecosystem services provides a useful framework for sustaining military testing and training capabilities by linking the natural resources controlled by the military to the regional context that will impact these resources over the long term. This concept can potentially bring training land managers more actively into the ongoing sustainability conversations at installations, which tend to be dominated by energy, waste and pollution prevention stakeholders. The concept can help bridge the divide between environmental and mission concerns and support the triple bottom line. 


\subsection{Objective}

The objective of this report is to summarize the latest literature on ecosystem services in science and policy, and then to describe ways in which emerging applications of this concept may impact military planning and policy.

\subsection{Approach}

The research conducted in support of this report involved a literature review. The first component was a review of US government agency webbased resources, searching with the term "ecosystem services." The second was a search of electronic journals using the same search term, and reviewing a limited selection from 2009 and 2010. Other articles were obtained that were frequently cited within the recent literature that could provide background to recent developments. Recently published books (2009 and 2010) with the term in the title were reviewed. The final step was to search websites of nonprofit organizations that are focused on promoting this concept for biodiversity conservation, for improvement of human well-being, and for establishing ecosystem service markets.

\subsection{Scope}

This literature review was not intended to be a meta-analysis of published research and policy documents because the published literature on this topic has grown exponentially over the past decade. Rather, the review was intended to capture significant trends based on analysis and reviews completed by others or to review the very latest in ecosystem service thought and relate it to the military mission. The results are organized in four sections following this introduction. The first presents an overview of the concept and its recent adoption by major science and policy stakeholders. The second reviews some of the recent applications of the concept. The third section links the applications to military activities. The final section provides some initial conclusions about the significance of the term to the DoD and recommendations for next steps.

\subsection{Mode of technology transfer}

This report is being transmitted to military policymakers and managers responsible for implementing land and installation sustainability initiatives for the Army. This report served as the basis for an Army Environmental Policy Institute (AEPI) Foresight Bulletin, “J une 2011: Protecting 
Critical Benefits Received from Ecosystems," which is available at http:// www.aepi.army.mil. Foresight Bulletins introduce a specific topic, discusses the topic's importance to the Army, and highlight several key areas for further study. In addition, this report will be publicly accessible via the ERDC library archive at http:// acwc.swdp.sirsi.net/ client/ default. 


\section{Adoption of the Concept}

There has been much research and thought devoted to the relationship of nature and human well-being. The concept of ecosystem services is one of many lines of research on this relationship, and it initially emerged in the 1970s (Small and Lewis 2009). The concept was solidified recently as a result of several highly cited publications (Costanza 1997; Daily 1997) and the Millennium Ecosystem Assessment (MA). ${ }^{1}$ The MA was commissioned by the United Nations and published a framework in 2003 and a synthesis in 2005 (MA 2003, 2005). The results describe types of ecosystem services in a classification scheme that continues to be used in research and policy (Figure 1). The MA conducted a global assessment of the state of ecosystem services and found that 60 percent of ecosystems were degraded or used unsustainably. By publishing a definition of the ecosystem services concept, the MA served to connect and highlight much of the research and discussion in the areas of conservation, natural resource management, and environmental economics. It also focused attention on the rapidly declining state of these critical life-support systems. Since publication of the MA reports, there has been a rapid expansion in ecosystem services-related research in many disciplines. It has proven to be a useful term for crossdisciplinary conversations but one that continues to be adopted and refined.

The MA defined ecosystem services simply as the benefits that people receive from ecosystems. There have been other classification and characterization frameworks developed to further specify the type of service and its relationship to ecosystem function, as the two terms are not synonymous (Boyd and Banzhaf 2007; Gómez-Baggethun and De Groot 2010). Ecosystem functions produce the services, but they are "services" only when human beings benefit. Humans benefit from both managed and natural ecosystems.

Most literature focuses on the services that come from natural ecosystems, but it is equally important to recognize those that come from heavily managed landscapes and cities (Bolund and Hunhammer 1999; Norris et al. 2010). This urban connection is evident in the planning world as a focus

\footnotetext{
${ }^{1}$ Reports and supporting information about the MA are available at http://www.maweb.org/en/index.aspx.
} 
on "natural" or "green" infrastructure for certain benefits (instead of manmade infrastructure)-wastewater treatment, erosion control, and recreational trail networks, in particular (Benedict and McMahon 2006; J affe 2010).

There are many ongoing efforts that attempt to fill the knowledge gaps identified by the MA and improve the quality of information about the condition of the world's ecosystems, such as those by the World Data Center for Biodiversity and Ecology. In the United States, efforts to assess ecosystem services include: the creation of the Ecosystem Services Research Program in the US Environmental Protection Agency (USEPA) and its National Atlas of Sustainable Ecosystem Services project; the National Geophysical Data Center Ecosystem Informatics; and the Heinz Center report series, "The State of the Nation's Ecosystems" (2002, 2008). The status of these efforts and others was not reviewed as part of this report, although it is important to note that many nonprofit and government efforts are underway to gather data on the conditions of ecosystems and their ability to support human well-being.

\section{ECOSYSTEM SERVICES}

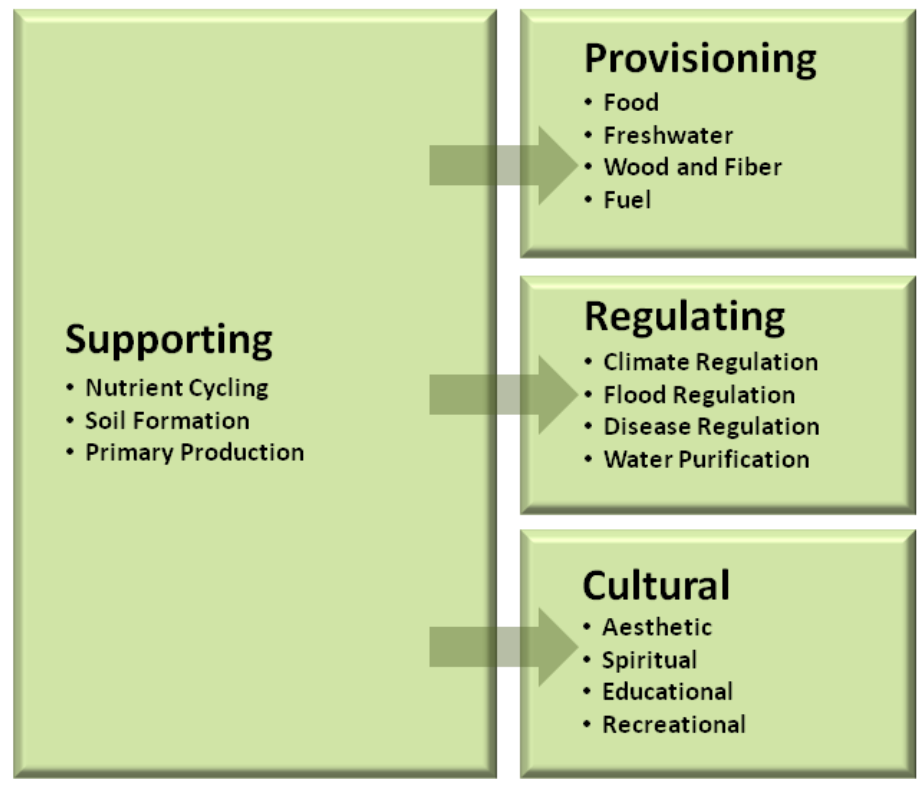

Figure 1. Millennium ecosystem assessment classification scheme (MA 2005). 


\section{Application of the Concept}

The concept of ecosystem services has proven to be a useful interdisciplinary term, with several fields of study adopting it as a framework for ecological research and economic accounting systems; for enhancing conservation; and for improving natural resource management outcomes. The various ways that the term has been applied have been mostly theoretical to date, with limited documented examples of the idea directly influencing decision making (Cox and Searle 2010; Cowling et al. 2008; Daily et al. 2009). Overall, the term is more commonly found in research and academic conversations, but there is a great deal of optimism among these communities that the concept will enable better decision making for the benefit of people and nature (Cox and Searle, 2010). There are significant challenges in the science and policy aspects of ecosystem services, but it is generally understood that if these values are not included in accounting and decision-making processes, they will not be adequately protected.

Two fundamental changes need to occur in order to replicate, scale up, and sustain the pioneering efforts currently underway to give ecosystem services weight in decision making. First, the science of ecosystem services needs to advance rapidly. Second, ecosystem services must be explicitly and systematically integrated into decision making by individuals, corporations, and governments. Without these advances, the value of nature will remain little more than an interesting idea that is represented in scattered, local and idiosyncratic efforts. (Daily et. al. 2009, 21- 22)

In this section, several examples of emerging applications of the concept will be reviewed including natural resource conservation, natural resource management, ecological economics, environmental impact assessment, and human health and well-being. Figure 2 summarizes concepts within each of these areas as they have brought ecosystem services into their lexicon. 

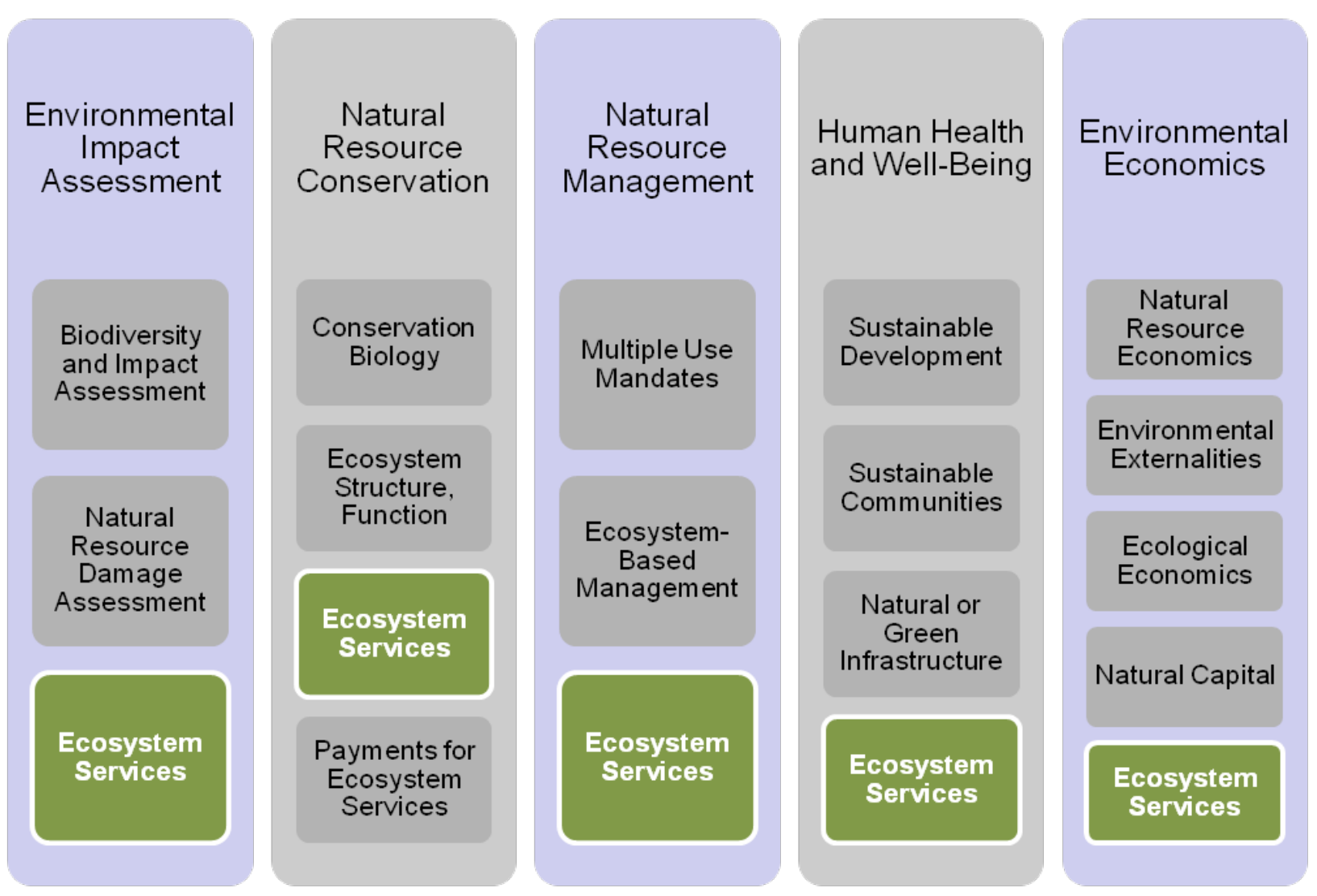

Figure 2. Application of the ecosystem services concept.

\subsection{Human health and well-being}

The purpose of the MA was to assess the consequences of ecosystem change on human well-being. This relationship continues to guide international aid organizations as strategies for improving the human condition are developed and implemented (United Nations Millennium Project 2005; USAID 2010; WRI 2005, 2008). The link between biodiversity, ecosystem services, and human health is increasingly the focus of research and policy making (Naeem et al. 2009a; Osvaldo et al. 2009; Ranganathan and Hazlewood 2010; Slootweg et al. 2010). This causal relationship is understood as:

biodiversity $\rightarrow$ ecosystem functioning $\rightarrow$ ecosystem services $\rightarrow$ human well-being

Evidence continues to accumulate that supports this link. There is now a "scientific consensus that biodiversity is critical for ecosystem function" (Solan et al. 2009, 42). A recent review of research found evidence of a direct biodiversity $\rightarrow$ ecosystem function $\rightarrow$ ecosystem service connection to human health through reduced disease transmission. As Keesing et al. 
stated, ".. A consistent picture has emerged - biodiversity loss tends to increase pathogen transmission and disease incidence" (2010, 647). Recent research is also focused on impacts of climate change to biodiversity and ecosystem services (Naeem et al. 2009b). Even with this growing body of evidence relating ecosystem well-being to human well-being, additional work is needed to translate the scientific data into decision-making contexts for the preservation of biodiversity and other ecosystem services. There are currently gaps in communication between the scientists who research the relationships between biodiversity and ecosystem services and the natural resource managers who are addressing "large-scale, real-world environmental problems" (Solan et al. 2009, 44).

The importance of improving and protecting ecosystem health is highlighted throughout the MA documents. As the statement below from the Health Synthesis (2005) states, reducing poverty, infant and maternal mortality, malnutrition, and other Millennium Development Goals (MDGs) will not be possible if the world's ecosystems continue to decline.

The ongoing degradation of ecosystem services is a significant barrier to achieving the MDGs.

Ecologically unsustainable use of ecosystem services raises the potential for serious and irreversible ecological change. This may occur on such a large scale as to have a catastrophic effect on the economic, social and political processes on which social stability, human well-being and good health depend. The MDGs give prominence to achieving reductions in malnutrition, infectious diseases, maternal mortality, exposure to unsafe drinking-water and, most importantly, poverty. All these goals are seriously jeopardized by continuing decline in the world's ecosystems. (Corvalan et al. 2005, 10)

There are critiques of the scientific research in ecosystem services and human well-being in regards to the ability of environmental scientists to appreciate and articulate what is meant by "well-being." There is an ongoing need for improved dialog among the natural and social sciences, but many researchers feel this is a strength of the concept of ecosystem services because it enables this communication (Cowling et al. 2008; Granek et al. 2010; Norris et al. 2010; Small and Lewis 2009). 
We are skeptical of efforts in ecosystem service research to include the human dimension and stakeholders because the projects are driven by biophysical data and (formally educated) experts; the ideas and concepts about what constitutes human well-being remain abstract, general, and static; and the projects involve people and their actual values very late in the process. (Menzel and Teng 2009, 907)

\subsection{Natural resource conservation}

Conservationists are adopting ecosystem services as a way to improve the success rate for protecting valuable natural areas and other natural resources. They believe successfully connecting human well-being with natural resource conservation will increase the resources devoted to conservation.

The concept presumes that conservation can best be achieved by explicitly linking nature to human wellbeing, and framing conservation in light of the services, or benefits, that any given ecosystem produces. Once people recognize this link, and the value provided to them by a given ecosystem, the impetus for conservation is born. (Cox and Searle 2009, 4)

Among conservation experts there is a debate as to whether the values of ecosystem services need to be quantified in dollars and traded in markets for true incorporation into decision making, or if simply recognizing these values exist is enough (Costanza 2006; McCauley 2006; Reid 2006). There also is debate by experts in this area around the possible negative side effects of pursuing preservation of single ecosystem service. Most of the conservation projects using ecosystem service approaches have been focused on protecting a single (albeit critical) service, which may have unintended consequences for biodiversity - the underlying objective of conservation biology and a less-effective approach overall (Cox and Searle 2009).

There is a great deal of research being conducted in this area as conservation organizations seek to prioritize investments as well as apply new funding mechanisms to achieve greater results. J oint efforts such as the 
Natural Capital project ${ }^{2}$ seek to characterize and quantify important services to help make the case for protection, with the main goal "to get people thinking regularly about ecosystem services as part of the direct cost or benefit of every decision" (Tallis et al. 2010, 12). One tool being developed is payment for ecosystem service (PES), which is a distinct alternative to the traditional approach of saving large blocks of critical natural habitat. PES programs pay landowners for specific types of management activities, while keeping the land in private hands. This is a fundamental shift away from the traditional perspective of "keeping the people out" to an appreciation of the dynamic relationship between nature, people, and economic drivers. Initial research on PES programs demonstrates favorable outcomes (Greenwalt and McGrath 2009).

Organizations have emerged that are focused on developing and promoting various market-based tools that can increase the amount of financial capital invested in conservation projects, one example being the Ecosystem Marketplace. ${ }^{3}$ This organization tracks a wide range of market-based mechanisms and, in the process, promotes these tools. The U. S. government has created an Office of Environmental Markets (OEM) within the United States Department of Agriculture (USDA) to enable continued growth of programs that subsidize the protection of valuable ecosystem services. "OEM has a unique role in the federal government's efforts to develop uniform standards and market infrastructure that will facilitate market-based approaches to agriculture, forest, and rangeland conservation."4

\subsection{Natural resource management}

The concept of ecosystem services is also influencing policy and practice in natural resource management. The guiding principles of ecosystem-based management and watershed-based management have been expanded to include the concept of ecosystem services, and research is being conducted in this area to understand tradeoffs and improve outcomes (Granek et al. 2010; Kareiva et al. 2007; Kline et al 2009).

\footnotetext{
2 Details on the Natural Capital Project can be found at: http://www.naturalcapitalproject.org/about.html

3 Details on the Ecosystem Marketplace can be found at: http://www.ecosystemmarketplace.com/

4 Excerpt from the OEM website: http://www.fs.fed.us/ecosystemservices/OEM/index.shtml
} 
The USDA Forest Service has taken a lead in exploring the significance of the concept for its forestry management practices. ${ }^{5}$ USDA Forest Service researchers have articulated the implications of an "ecosystem services approach" to managing national forests that contrasts with multiple-use and ecosystem-based approaches (Collins and Larry 2007). One change is that managers will view the landscape as containing stocks of natural capital, and the stocks and flows of these assets as part of their management responsibilities. They will need to ensure "the people who rely on these assets know their values and the cost of losing them" (ibid., 6). This is related to the need to connect ecosystem services to the people who benefit from them; management objectives become motivated by maintaining the supply and delivery of ecosystem services. Managers must also become more focused on anticipating future change and understanding the increasing societal needs for services from the land and resources they manage. "An ecosystem services approach underscores the importance of assessing alternative management strategies and takes demographic, economic, sociopolitical, and cultural factors into account, in addition to the direct drivers of ecosystem change" (ibid.). Finally, this approach requires natural resource managers to embrace a new language that captures a broader set of values; a language that will resonate with a greater percentage of the public.

\subsection{Environmental and ecological economics}

Valuation of ecosystem services continues to be an important topic in environmental economics. One of the fundamental drivers of the use of the term was to understand and account for all the values in economic exchanges. First described as environmental externalities, this area of research and policy has become increasingly sophisticated as more and more valuation studies are completed (Ruhl et al. 2007). Researchers have developed multiple methods to capture "total economic value" which "takes into account both the use and non-use values individuals and society gain or lose from marginal changes in ecosystem services" (Thornes 2010, 82). Guidance on how to quantify and capture ecosystem service values has been developed by the US Army Corps of Engineers (Pitts 2008) and the Office of the Secretary of Defense, Installations and Environment (ODUSD I\&E 2008). These first steps focus on dollar values because the economic valuation of ecosystem services is the easiest to translate into existing ac-

\footnotetext{
${ }^{5}$ Detailed listing of the resources developed by USDA Forest Service can be found at: http://www.fs.fed.us/ecosystemservices/resources.shtml
} 
counting and management systems, but they do not rule out other methods of valuation.

\subsection{Environmental impact assessment and mitigation}

A significant area of emerging ecosystem service application is related to implementation of existing regulatory, planning, and assessment frameworks. Ecosystem services are being (or proposed to be) incorporated into environmental impact assessment, mitigation for development impacts, and natural resource damage assessments. One of the implications of the increasing recognition of the link between biodiversity, ecosystem function, and ecosystem services is the incorporation of ecosystem service impacts into the environmental impact assessments (EIA) (Slootweg et al. 2010). Impacts to biodiversity can be connected with loss of important ecosystem services. Because the reduction of these services can have very real environmental and social costs, they should be part of the EIA process. Frameworks for incorporating ecosystem services in environmental impact assessment have been developed (Rajvanshi et al. 2010). The Council on Environmental Quality (CEQ) has developed recommended changes to the evaluation procedures for water resource projects in the United States, to explicitly consider the impacts to ecosystem service provision as part of the decision-making process (CEQ 2009). According to the CEQ:

Consideration of ecosystem services can play a key role in evaluating water resource alternatives. Using the best available methods in the ecological, social, and behavioral sciences to develop an explicit list of the services derived from an ecosystem is the first step in ensuring appropriate recognition of the full range of potential impacts of a given alternative. This can help make the formulation and the analysis of alternatives more transparent and accessible and can help inform decision makers of the full range of potential impacts stemming from different options before them. The second step is establishing the significance or value of changes in the quality or quantity of services over time, with and without the effects of proposed alternatives on ecosystem services (CEQ 2009, $5)$. 
A second implication of the increasing recognition of the link between biodiversity, ecosystem function, and ecosystem services can be found in the management of negative environmental impacts associated with development projects. This is a logical follow-on to the incorporation of ecosystem services in EIA - the need to mitigate negative impacts that are identified. The incorporation of the impacts to ecosystem services on the front end (via the impact assessment process) implies avoidance, mitigation, and offset of these impacts. Existing legal requirements under the Clean Water Act (CWA) and the Endangered Species Act (ESA) are already focused on the recognition and mitigation of negative impacts to important natural resources, but the concept of ecosystem services will expand the range of impacts that should be incorporated and accounted for. The concept of biodiversity offsets as an additional tool for reducing the negative impacts of development projects can also be justified through the use of ecosystem services.

Communities use a variety of tools to offset negative impacts of development, with infrastructure fees being one common approach. Using ecosystem services as the performance metric -or the values that must be accounted for if damaged -is not so far off for the "next step." Washoe County in Nevada has instituted a "no net loss" of ecosystem services policy as part of the evaluation process for approval of new development. Using a participatory planning process, the community is identifying areas with high ecosystem service provision values (such as recreation) to help guide green space planning and acquisition. Development fees can then be used to mitigate impacts to ecosystem services while advancing the county's green space plan (Manson 2010).

Natural Resource Damage Assessments (NRDA) are conducted after spills or releases of chemicals to determine the level of harm suffered by impacted parties. "During the NRDA process, injuries (harm) to valuable ecological resources and habitats, and the subsequent loss of the ecological or human services provided by them, are estimated and translated or scaled by the trustees into restoration projects" (Stahl et al. 2007, 7). As the valuation and assessment tools become increasingly sophisticated, so will the estimates of damage associated with spills and releases under Comprehensive Environmental Response, Compensation, and Liability Act (CERCLA or Superfund) and the Oil Pollution Act (OPA). The concept of ecosystem services is also being incorporated into Cost Benefit Analysis (Bolund and Hunhammer 1999) and Life Cycle Cost Assessment (Azapagic 2010). 


\section{Implications for the Department of Defense}

This review of literature about recent developments in ecosystem science and policy reveals three main areas that have implications for the DoD: (1) strategic planning in support of operations, (2) natural resource management, and (3) compliance and markets. This section will review these areas and possible implications.

Previous research also examined implications of the concept of ecosystem services for the DoD. The overlap between previous efforts and this work on current trends demonstrates the continued relevance of science and policy based on ecosystem services. Previous work includes the following:

- A Foresight Report prepared for the AEPI examined the role that markets focused on ecosystem services could play in supporting sustainably goals of Army installations (Keysar and Eady 2006).

- A white paper prepared by the US Army Corps of Engineers' (USACE) ERDC-CERL on the importance of ecosystem services to the military identified four areas of relevance: sustained resource capability; natural and/or open spaces; regional ecosystem habitats and pathways; potential expansion or expanded use opportunities (Goran 2006).

- A Foresight Bulletin prepared by the AEPI reviewed implications of ecosystem service markets for the military (AEPI 2007).

- A technical report prepared with ERDC-CERL examined the various ways the provision of ecosystem services is secured through marketlike mechanisms by using both existing and possible applications (Keysar and Goran 2008).

- A workshop report prepared for SERDP presented areas of research needed to enable the DoD to utilize the concept of ecosystem services more effectively for biodiversity preservation and comprehensive land management (TNC 2008). This effort utilized input from subject matter experts and resulted in a new area of research for Environmental Security Technology Certification Program (ESTCP) expressed as: "Ecosystem Service Methodologies and Tools." Research will be funded in this area for the first time in 2011.

- A technical report prepared for the AEPI examined the relationship between environmental factors and state fragility indices (Alcorn et al. 2010). This research highlighted the lack of information on the capacity of ecosystems to provide ecosystem services essential to human health and well-being. 
Table 1 depicts the areas of ecosystem service science and policy identified through this report and the relationship of these areas to the three main areas of implications for the DoD. As seen in the table, there continues to be relevance as implications continue to be articulated beyond those related to ecosystem service markets and natural resource management. This expanding scope can be attributed to increasing adoption of the concept of ecosystem services in research, planning, and policy arenas combined with changes in the operational paradigms within the DoD. Another influence is the increasing opportunities in ecosystem service markets that can improve environmental compliance outcomes.

Table 1. Emerging areas of ecosystem services science and policy.

\begin{tabular}{|c|c|c|}
\hline $\begin{array}{l}\text { Area of Ecosystem Service } \\
\text { Science and Policy }\end{array}$ & $\begin{array}{l}\text { Area of Implications } \\
\text { for the DoD }\end{array}$ & Previous Area Researched* \\
\hline Human health and well-being & $\begin{array}{l}\text { Strategic planning in support } \\
\text { of operations }\end{array}$ & State fragility indicators \\
\hline \multirow{2}{*}{$\begin{array}{l}\text { Natural resource } \\
\text { conservation }\end{array}$} & \multirow{4}{*}{$\begin{array}{l}\text { Natural resource } \\
\text { management }\end{array}$} & Sustained resource capability \\
\hline & & $\begin{array}{l}\text { Regional ecosystem habitats } \\
\text { and pathways }\end{array}$ \\
\hline \multirow{2}{*}{$\begin{array}{l}\text { Natural resource } \\
\text { management }\end{array}$} & & Natural and/or open spaces \\
\hline & & $\begin{array}{l}\text { Potential expansion or } \\
\text { expanded use opportunities }\end{array}$ \\
\hline \multirow{2}{*}{$\begin{array}{l}\text { Environmental and ecological } \\
\text { economics }\end{array}$} & \multirow{3}{*}{ Markets and compliance } & $\begin{array}{l}\text { Market-based approaches to } \\
\text { provision of ecosystem } \\
\text { services }\end{array}$ \\
\hline & & $\begin{array}{l}\text { Market-based approaches to } \\
\text { achieving sustainability } \\
\text { objectives }\end{array}$ \\
\hline $\begin{array}{l}\text { Environmental impact } \\
\text { assessment and mitigation }\end{array}$ & & \\
\hline
\end{tabular}

*Alcorn et al. 2010; Goran 2006; Keysar and Eady 2006; Keysar and Goran 2008; TNC 2008

\subsection{Strategic planning in support of contingency operations}

The first area of implications for the DoD of emerging ecosystem services science and policy is in strategic planning in support of contingency operations. US national security policy has historically been nation-state centric and focused on defending against and responding to external threats. The 
events of September 11, 2001, and engagements since then have served to focus attention on the critical relevance of failed states, non-state actors, and their challenges to US national security interests. There has been a shift by US policymakers, thought leaders, and practitioners from a more "traditional" national security frame toward a more "human security" approach, apparent with the demands of counterinsurgency and stability, security, transition, and reconstruction (SSTR) operations (Kaldor and Beebe 2010). Environmental issues, including availability of ecosystem services, are increasingly being recognized as core supporting elements for the maintenance of state stability. Environmental issues play a critical role in human and societal welfare by providing the "foundation" for the most basic of physiological needs (e.g., water, food, shelter) (Alcorn et al. 2010). This national security and ecosystem service connection was also noted by the MA Board:

Loss of natural services in poor regions affects people with far fewer alternatives to protect their livelihoods. This can also put high financial and political strains onto the international community, either through increased disaster relief, the need to intervene in regional conflicts, or the migration of refugees. (Watson and Zakri 2005, 20)

Research on the relationship of ecosystem services to human well-being, along with spatial distribution of important ecological indicators, could enhance strategic planning and assessment of locations in the world where the DoD could become engaged. This is compatible with a "whole-ofgovernment approach" to security issues, as called for by the 2010 Quadrennial Defense Review (QDR) and the 2010 National Security Strategy.

\subsection{Natural resource management}

The second area of implications for the DoD of emerging ecosystem services science and policy is in natural resource management. The DoD is highly dependent upon ecosystems to complete its mission. The benefits from healthy ecosystems that the DoD enjoys are almost entirely related to landscapes being available for training. DoD installations are found in a variety of ecosystem types such that realistic training environments are available for any possibilities that contingency forces may face around the globe. These ecosystems allow the military to simulate conditions from arctic (Fort Richardson in Alaska) to tropical (Fort Stewart in Georgia) to 
desert (Twentynine Palms in California). The DoD has therefore established successful range and training land management programs to protect the continual flow of ecosystem services from these landscapes. For instance, vegetative cover is important to protect ranges from erosion. The Army's Sustainable Range Program (SRP) ${ }^{6}$ with the Integrated Training Area Management (ITAM) and Range and Training Land Programs (RTLP) are examples of the cooperation between range managers and natural resource professionals at Army installations that are designed to maintain the flow of benefits from the land to those who train on it.

The concept of natural infrastructure (NI) has emerged within the DoD to help account for and manage important natural assets. The Air Force and Army have incorporated this concept into asset accounting systems (Rawlins 2009; Waite 2009). The NI concept is focused on the status of important air, land, and water resources in support of mission accomplishment based on existing conditions. Implementation of the Army's NI reporting system through the Installation Status Report (ISR) is still in the early stages. It is not yet clear if this reporting system will enable improved decision making or support regulatory compliance. Leadership has recognized the importance of relating ecosystem attributes to achieving mission success, but there is still a need to understand the "opportunity" or "shadow" costs associated with investments in natural resources. Existing tools are not yet capturing this information. Furthermore, the NI concept while it overlaps with ecosystem services - is not the same. The use of this term is also very limited outside the DoD, and this will impact the DoD's ability to communicate with outside stakeholders on these issues in the future, especially at the regional scale.

The concept of ecosystem services is therefore not new for the land managers within DoD, it is simply a new way of expressing what they already understand and appreciate. It would not appear, at first, that the concept of ecosystem services could enhance efforts that already exist to manage natural resources that support the DoD mission. There are advantages for adopting the concept, however. The first advantage is related to measurement, valuation, and assessment tools that can enable improved comparison of alternative land management techniques on an installation. Multiple research efforts are underway by federal agencies, academic institutions, and non-profits which are designed to understand and articu-

${ }^{6}$ Details on the Army's Sustainable Range Program can be found at: http://aec.army.mil/usaec/range/sustainment00.html 
late the impact that land use decisions have on the flow of ecosystem services. The inclusion of ecosystem services in the decision-making process can help ensure long-term sustainability of multiple benefits from ecosystems. If these benefits are not articulated, they do not get considered in decisions. Figure 3 depicts the change in provision of ecosystem services (in this case, just four: climate regulation, water supply, erosion control/soil fertility and mission support) as land is more intensively used for training (from left to right in Figure 3). The possible end result is that the ranges are used so intensely that they are not capable of supporting the full range of mission needs. This graphic helps explain the land management trade-offs from inside the fenceline.

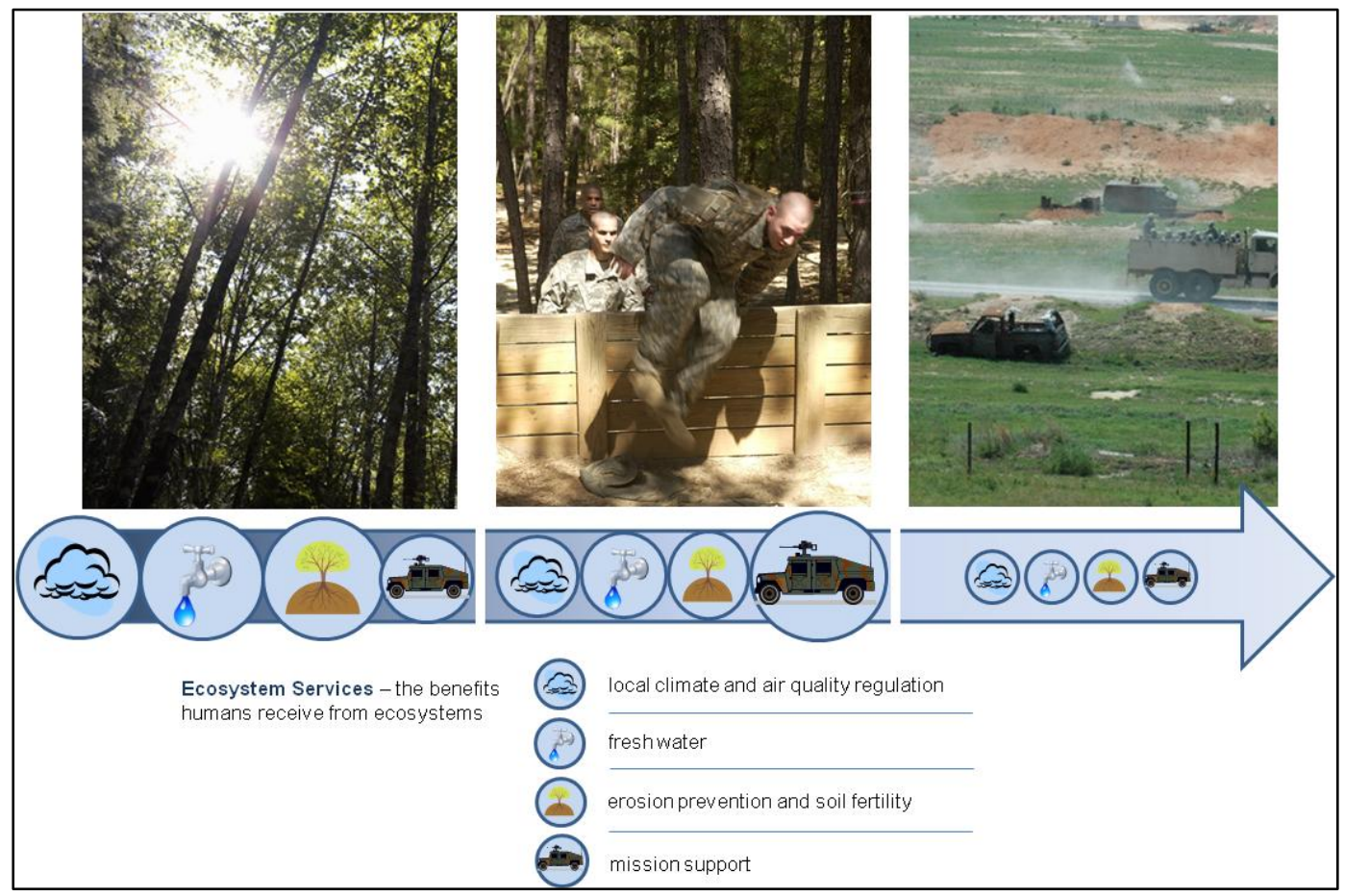

Figure 3. Changes in ecosystem service provision with changes in land use.

A second advantage is in improved understanding of the impacts of landuse changes outside the fence. Military installations depend on ecosystem services that originate outside the fenceline - services the DoD does not control but nonetheless benefits from. Table 2 lists some of these in relation to various land uses and performance metrics. Existing encroachment management tools, such as the Army Compatible Use Buffer (ACUB) Program, and compliance tools, such as wetland mitigation banking, could benefit from the inclusion of the ecosystem services perspective. The identification and valuation of various services in relation to land use can help set priorities for conservation easements. This information can also help 
when mitigation is required for on-post impacts to regulated natural resources. As the research conducted for this report demonstrates, the ecosystem services terminology is becoming more commonplace among nonprofits and regulatory agencies that impact land use near installations and are developing environmental markets. It will be advantageous for the DoD to adopt terminology that resonates with partners outside the fence.

Table 2. Examples of ecosystem services relevant to the DoD from off-post land uses.

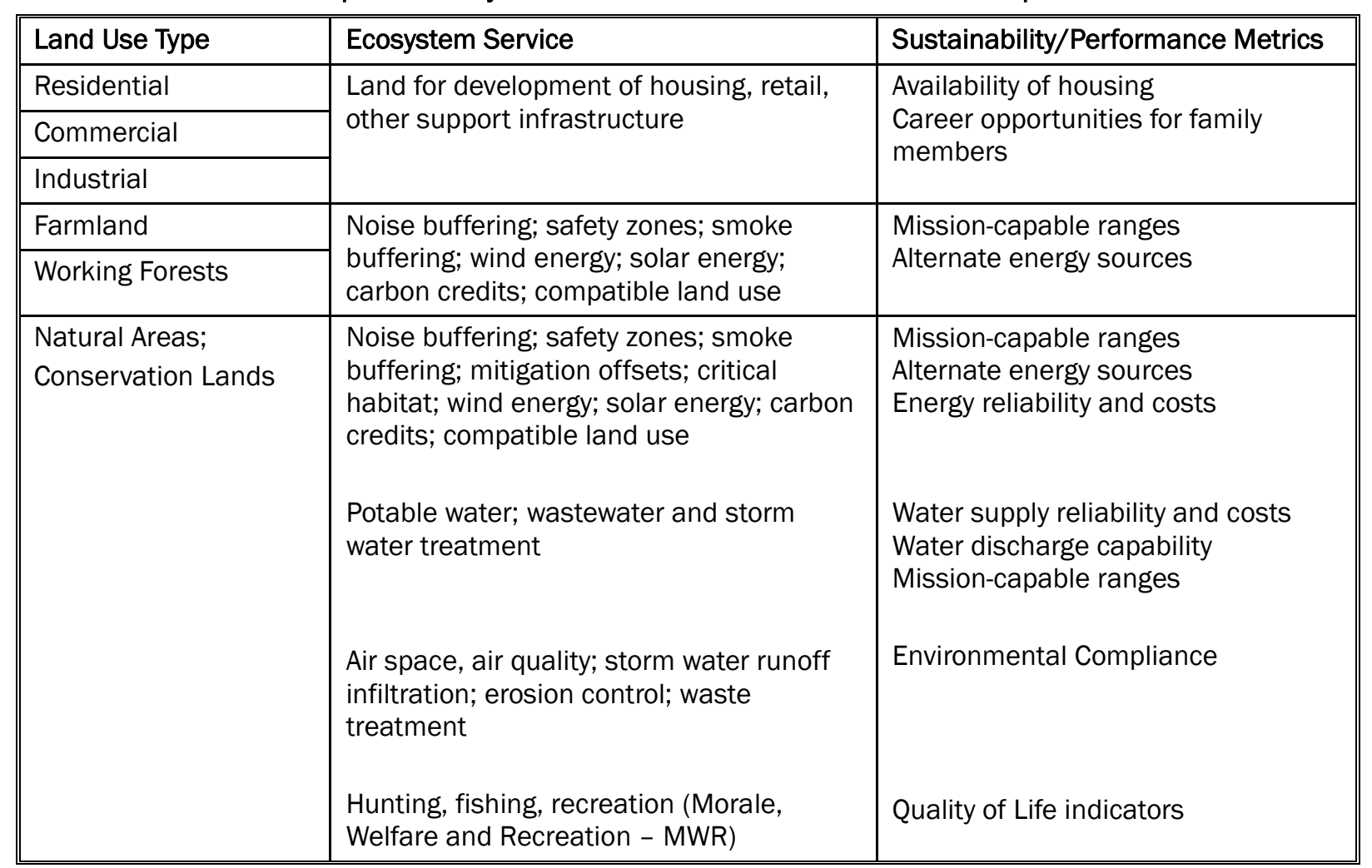

\subsection{Compliance and markets}

The final area of implications for the $\mathrm{DoD}$ are those related to regulatory compliance and emerging markets. It is unlikely that ecosystem services will be the subject of protection under federal legislation in the near future. It is likely, however, that protection of an ecosystem service provision will be addressed by using it as a performance metric under existing authorities. For example, guidance for granting permits under the CWA has recently expanded to require USACE to consider the impact to ecosystem services when determining appropriate mitigation (Ruhl 2010). Agencies have flexibility in implementing law and using ecosystem services as a performance metric to determine compliance with the law is probable - even 
if the law itself does not use the term. Ecosystem services protection may therefore find its way into several statutory requirements, for example:

- $\quad$ under planning and priority setting tools, such as the National Environmental Policy Act (NEPA), natural resource management plans within agencies (Sikes Act), and the Water Resources Development Act;

- $\quad$ under mitigation and reimbursement requirements, such as the CWA permitting process, Federal Regulatory Commission relicensing, and NRDA (already underway for the Gulf Coast oil spill); and

- $\quad$ under grant and loan programs, such as revolving fund loans under the Safe Water Drinking Act and CWA, as well as the Conservation Reserve Program (CRP). ${ }^{7}$

Corporations that are incorporating ecosystem services into decisionmaking and accounting systems are doing so both to manage future risks and to take advantage of opportunities, as these services have values that can be captured in the marketplace (ENS 2011). On the regulatory side, corporations seek to manage risks related to "new fines, new user fees, government regulations, or lawsuits by local communities that lose ecosystem services due to corporate activities" (WRI 2008b, 7). Likewise, there are opportunities to engage with governments "to develop policies and incentives to protect or restore ecosystem that provide services a company needs" (ibid). As noted by the World Resource Institute's (WRI) recent work in "The Corporate Ecosystem Services Review":

Likewise, environmental management systems and environmental due diligence tools are often not fully attuned to the risks and opportunities arising from the degradation of ecosystems and the services they provide. For instance, many tools are more suited to handle "traditional" issues of pollution and resources consumption. Most focus on environmental impact, not dependence. Furthermore, they typically focus on risks, not business opportunities. Consequently, companies may be caught unprepared or miss new sources of revenue associated with ecosystem change. (WRI 2008b, 8)

\footnotetext{
7 These observations are based on a briefing made by Lynn Scarlett at the 2010 ACES conference in Phoenix, Arizona, for which she did not use PowerPoint slides.
} 
The DoD is similar to corporations in this regard - it needs to be ready for new regulations, but also remain ready to protect the ecosystems that provide it with services essential to mission accomplishment (refer back to Table 2). 


\section{Conclusion and Recommendations}

The purpose of this report was to summarize the latest literature on ecosystem services in science and policy, in order to describe ways in which emerging applications of this concept may impact military planning and policy. This review has shown a continued relevance of the term through its increasing adoption by many federal agencies, academic institutions, and non-profit organizations. The strength of the term is in its ability to connect diverse conversations in economics, conservation, natural resource management, and sociology. It supports achievement of sustainability goals by linking natural capital with financial capital and by revealing the value of ecosystem functions - values that are currently excluded from market transactions and other important decision-making processes. Although debate about specific definitions will continue, it does not appear the term will be replaced.

The concept of ecosystem services can assist the military in making natural resources decisions today for improved outcomes in the long term. It is completely in line with sustainability goals and objectives, and with operations based on the principle of sustainability. The issue appears to be more about language than relevance, since recognition of the need to protect natural resources is already widely accepted within the DoD - an example is its use of the term "Natural Infrastructure." The question remains if the vocabulary currently used by the $\mathrm{DoD}$ is helping decision makers address these needs and if it is critical for the DoD to be in alignment with other agencies and conservation partners. This report demonstrates many reasons why the DoD should move forward in the adoption of this concept. These include the need for DoD: (1) to successfully engage with stakeholders on conservation issues; (2) to utilize new tools and data sources in decision making; and (3) to be prepared for new regulatory requirements. It is clear that other agencies are moving forward with the language and concepts associated with ecosystem services, not only across the United States but also around the world. As noted by a DoD natural infrastructure subject matter expert, "DoD is late to the party."

Adopting the concept of ecosystem services will only serve to enhance the DoD's ability to interact with external partners, improve decision-making 
processes, and comply with environmental regulations. It is therefore very timely to enhance the institutionalization of the concept, and this can be done through training and conferences for natural resource management professionals, environmental compliance professionals, those that plan for future DoD contingency operations, and the training community that seeks to ensure ongoing access to ranges and training lands.

Based on the findings of this report, it is recommended that the DoD move forward with institutionalizing the concept of ecosystem services. Three methods for doing this are suggested: (1) additional research, (2) additional engagement, and (3) additional training and outreach.

\subsection{Additional research}

\subsubsection{Measurement and analytical tools}

The military services should continue to support research that seeks to quantify the provision of ecosystem services, the values association with these services, and management actions that can ensure provision of important services into the future. Initial funding by ESTCP in this area is important, as well as continued efforts through USACE. These efforts should be expanded and coordinated with other research performed by academic and nonprofit entities.

\subsubsection{Review of existing reporting and decision-making tools}

Good ideas in the DoD often get repeated, resulting in overlap and redundancies. A thorough evaluation of existing reporting and decision-making tools related to ecosystem services is needed to ensure a renewed focus builds on these and does not confuse stakeholders. It would also help to learn from the knowledge gained from implementation of these existing tools. A policy and reporting system evaluation would include the Army's ISR-NI reporting mechanism and the Air Force's Natural Infrastructure Management (NIM) program, along with other tools used by the DoD to incorporate the status of natural assets in decision making. The research should seek to determine if the desired outcomes associated with ISR-NI and NIM have been achieved and if not, why not. The evaluation would provide recommendations for use of the data currently being collected for addressing risks associated with loss of ecosystem services as well as ways to shift the language to one based on ecosystem services. 


\subsubsection{Review of existing management practices}

The DoD adopted ecosystem-based management for natural resources as policy in 1996 and then updated that policy in 2011 (DoD Instruction 4715.03). Case-study research completed in 2002 indicated that many challenges exist to implementing ecosystem-based management principles at DoD installations (Fittipaldi and Wuichet 2002). The primary tool for implementing ecosystem-based management is the Integrated Natural Resource Management Plan (INRMP). This report found the concept of ecosystem services is a further extension of the principles of ecosystem-based management. Therefore, it is relevant and timely to once again assess the status of ecosystem-based management in light of existing requirements and future needs. That evaluation would include an assessment of the possible contribution that the ecosystem services concept may have in enhancing the ongoing efforts of DoD land managers by incorporating the concept into a INRMP at an installation that is updating and revising its plan.

\subsubsection{Demonstration and validation}

There is a pressing need to demonstrate the applicability of the concept of ecosystem services in real-life management and decision making. This is not only a need for the military, but also a need for other government agencies such as EPA and USDA, and for non-profit advocacy organizations such as The Nature Conservancy. Current military installation management is focused on achieving a single goal at a time - such as ESA compliance, noise buffering, or water supply infrastructure. An ecosystem service framework can help decision makers apply a systems-based perspective. It can help link goals both internally and externally so that mutu$\mathrm{al}$ and overlapping objectives can be identified. This type of thinking is necessary to sustain the mission over the long term.

In order to move in this direction, demonstration projects are needed. A demonstration site would involve developing a framework by which the concept of ecosystem services could be adopted in land management. It could focus on application of the concept to improve the process by which ACUB sites are selected. Or, it could be used to enable improved outcomes in wetland mitigation or to reduce internal encroachment pressures. The demonstration would involve adaptation of existing measurement and mapping tools, stakeholder engagement, and evaluation of outcomes. Installation land managers need additional support to move themselves and 
their regulators to a new way of thinking that goes beyond traditional stovepipes and includes a fuller range of relevant values.

\subsection{Additional engagement}

\subsubsection{Federal partners}

The DoD should actively engage in ongoing conversations with other federal agencies about developing ecosystem services policy, conducting ecosystem services research, and creating ecosystem services markets. There are multiple ways to do this. One is to invite key individuals from these agencies in for meetings or briefings to share what their agencies are doing. Another is to become an active member of the National Ecosystem Services Partnership (NESP). NESP is a forum for the sharing of ideas and lessons learned. It provides one existing avenue to engage with other federal agencies. Memorandums of Understanding (MOUs) can be developed and signed at the headquarters level to encourage local agency representatives to implement innovative solutions.

\subsubsection{Local regulators}

Active engagement is also needed with the regulatory community. Regulators need to be brought along with this new way of thinking. They need to appreciate this perspective and how it takes the DoD beyond regulatory compliance to preservation and restoration of important ecosystem functions. Current regulatory enforcement is very focused on the natural resources on-post, limiting innovative solutions that extend beyond the fenceline or even within an ecoregion. Pilot projects need to be initiated that involve regulators working toward an ecosystem services approach to compliance and resource management, both within and outside the military fenceline. At the same time, headquarters-level personnel need also to be educated about new possibilities that will encourage the field to allow these approaches to be implemented.

\subsubsection{Corporate examples}

The DoD should continue to learn from the corporate world as additional companies are adopting proactive, ecosystem service-based approaches to asset management and regulatory compliance. Policy research reviewing these efforts and lessons learned is recommended for the DoD. Engaging speakers from corporate best practices also is a useful way to socialize the concept and its application. 


\subsection{Additional training and outreach}

\subsubsection{Environmental and planning professionals}

Environmental professionals within the military that prepare NEPA assessments, ESA management plans, INRMPs, and Master Plans for installations already have the institutional knowledge to appreciate what an ecosystem service is and why it is important to consider in decision making. Training modules are needed to socialize the language and concepts, along with possible applications to practice. With this awareness, environmental and planning professionals can begin to improve practice and to push for changes across the stovepipes that impact the achievement of the goals set forth in the planning process. The training will help these professionals find ways to integrate existing management tools into a more holistic approach instead of focusing on managing a specific species or land area. Conferences such as the Federal Planning Division's annual workshop, the Sustaining Military Readiness Conference, and the Environment, Energy, and Sustainability Symposium are possibilities for such training.

\subsubsection{Training land management professionals}

Land management professionals within the military that prepare RTLPs, articulate ACUB priorities, and justify Air Installation Compatible Use Zones (AICUZ) will tend to be focused on a particular dimension. They should be looking across the dimensions - not just at the primary focus of noise, smoke, safety, endangered species, or wetland acres - but all of these together. The concept of ecosystem services can help these land management professionals articulate the benefits obtained from ecosystems that support the mission in a systems-based perspective. Training modules are needed to socialize the language and concepts, along with possible application to practice. With this awareness, land managers will be able to integrate existing management tools into a more holistic approach.

\subsubsection{Environmental security}

Professionals that work within the operational planning and forecasting community have an appreciation for the links between ecosystem health and human well-being. The establishment of the Army's African Command (AFRICOM) is an expression of this awareness. Continued outreach to this community about the role that environmental considerations can play in their planning processes - to include the concept of ecosystem services will enhance appreciation of this link and its impacts on the military mis- 
sion in the future. This should be done in coordination with other partners in the "whole-of-government" approach. 


\section{References and Resources}

\section{References}

Alcorn, J., T.Vincent, S.Clark, E. Keysar, and E. Moses. 2010 "Environmental Factors in Forecasting State Fragility." Washington, DC: Army Environmental Policy Institute.

AEPI (Army Environmental Policy Institute). 2007. "Emerging Ecosystem Services and Markets." AEPI Foresight Bulletin. Arlington, VA: AEPI. Available at: http://www.aepi.army.mil/publications/foresight/.

Azapagic, A. 2010. "Life Cycle Assessment as a Tool for Sustainable Management of Ecosystem Services." In Issues in Environmental Science and Technology, \#30 Ecosystem Services, edited by R.E. Heister and R. M. Harrison. Cambridge, UK: RSC Publishing.

Benedict, M.A., and E.T. McMahon. 2006. Green Infrastructure: Linking Landscapes with Communities. Washington, DC: Island Press.

Bolund, P. and S. Hunhammer. 1999. "Ecosystem Services in Urban Areas." Ecological Economics 29: 293-301.

Boyd, J . and S. Banzhaf. 2007. “What Are Ecosystem Services? The Need for Standardized Environmental Accounting Units." Ecological Economics 63(3): 616-626.

CEQ (Council on Environmental Quality). 2009. "Proposed National Objectives, Principles and Standards for Water and Related Resources Implementation Studies." Washington, DC: White House Council on Environmental Quality. Available at: http://www.whitehouse.gov/administration/eop/ceq/initiatives/PandG.

Collins, S. and E. Larry. 2007. "Caring for Our Natural Assets: An Ecosystem Services Perspective." Portland, OR: United States Department of Agriculture, Forest Service, Pacific Northwest Station.

Corvalan, C., S. Hales, and A. McMichael. 2005. "Ecosystems and Human Well-Being: Health Synthesis.” Report of the Millennium Ecosystem Assessment, Geneva; Switzerland: World Health Organization. Available at: http://www.maweb.org/en/index.aspx.

Costanza, R., R. d'Arge, R. de Groot, S. Farber, M. Grasso, B. Hannon, K. Limburg, S. Naeem, R. O’Neill, J. Paruelo, R. Raskin, P. Sutton, and M. van den Belt. 1997. "The Value of the World's Ecosystem Services and Natural Capital." Nature 387(15): 253-260.

Costanza, R. 2006. “Nature: Ecosystems without Commodifying Them." Nature 443(7): 749.

Cox, S. and B. Searle. 2009. “The State of Ecosystem Services.” Boston, MA: Bridgespan Group. 
Cowling, R.M., B. Egoh, A.T. Knight, P.J . O’Farrell, B. Reyers, M. Rouget, D.J . Rous, , A. Welz, and A.W. Wilhelm-Rechman. 2008. "An Operational Model for Mainstreaming Ecosystem Services for Implementation." Proceedings of the National Academy of Science 105(28): 9483-9488.

Daily, G. 1997. Nature's Services: Societal Dependence on Natural Ecosystems. Washington, DC: Island Press.

Daily, G.C., S. Polasky, J . Goldstein, P.M. Kareiva, H.A. Mooney, L. Pejchar, T.H. Ricketts, J. Salzman, and R. Shallenberger. 2009. "Ecosystem Services in Decision Making: Time to Deliver." Frontiers in Ecology and the Environment 7(1): 21-28.

DODI 4715.03. 2011 “Natural Resources Conservation Program.” Washington, DC: Under Secretary of Defense for Acquisition, Technology and Logistics (USD[AT\&L]).

ENS (Environmental News Service). 2011. "Dow Chemical Partners with the Nature Conservancy to Improve Sustainability." Detroit, MI: ENS. Available at: http://www.ens-newswire.com/ens/jan2011/2011-01-24-091.html.

Fittipaldi, J ., and J . Wuichet. 2002. “Department of Defense Ecosystem Management Policy Evaluation.” AEPI-IFP-0802F. Washington, DC: AEPI.

Gómez-Baggethun, E. and R. De Groot. 2010. "Natural Capital and Ecosystem Services: The Ecological Foundation of Human Society." In Issues in Environmental Science and Technology, \#30 Ecosystem Services, edited by R.E.Heister and R. M. Harrison. Cambridge, UK: RSC Publishing.

Goran, W. 2006. "Ecosystem Services: Exploring Their Potential Importance to the U.S. Military." Champaign, IL: US Army Engineer Research and Development Center, Construction Engineering Research Laboratory.

Granek, E.F., S. Polasky, C.V. Kappel, D.J . Reed, D.M. Stoms, E.W. Koch, C.J . Kennedy, L.A. Cramer, S.D. Hacker, E.B. Barbier, S. Aswani, M. Ruckelshaus, G.M.E. Perillo, B.R. Silliman, N. Muthiga, D. Bael, and E. Wolanski. 2010. "Ecosystem Services as a Common Language for Coastal Ecosystem-Based Management." Conservation Biology 24(1): 207-216.

Greenwalt, T. and D. McGrath. 2009. “Protecting the City's Water: Designing a Payment for Ecosystem Services Program." Natural Resources and Environment. 24(1): 914.

Heinz Center. 2008. The State of the Nation's Ecosystems: Measuring the Lands, Waters, and Living Resources of the United States. Washington, DC: Island Press.

J affe, M. 2010. “Reflections of Green Infrastructure Economics.” Environmental Practice 12(4): 357-365.

Kaldor, M. and S. Beebe. 2010. The Ultimate Weapon is No Weapon: Human Security and the New Rules of War and Peace. New York, NY: PublicAffairs. 
Kareiva, P., S. Watts, R. McDonald, and T. Boucher. 2007. "Domesticated Nature: Shaping the Landscapes and Ecosystem for Human Welfare." Science 316:18661869.

Keesing, F., L.K. Belden, P. Daszak, A. Dobson, C.D. Harvell, R.D. Holt, P. Hudson, A. J olles, K.E. J ones, C.E. Mitchell, S.S. Myers, T. Bogich, and R.S. Ostfeld. 2010. "Impacts of Biodiversity on the Emergence and Transmission of Infectious Diseases." Nature 468: 647-652.

Keysar, E. and D. Eady, 2006. "AEPI Foresight Report: Market-Based Approaches for Achieving Sustainability Objectives.” Arlington, VA: AEPI.

Keysar, E. and W. Goran. 2008. "Provision of Ecosystem Services through Market-Based Approaches: Department of Defense Applications." ERDC/ CERL SR-08-4. Champaign, IL: US Army Engineer Research and Development Center, Construction Engineering Research Laboratory.

Kline, J .D., M.J . Mazzotta, and T.M. Patterson. 2009. "Toward a Rational Exuberance for Ecosystem Services Markets.” J ournal of Forestry 107(4): 204-212.

MA (Millennium Ecosystem Assessment). 2003. Ecosystem and Human Well-Being: A Framework for Assessment. Washington, DC: Island Press. . 2005. Ecosystem and Human Well-Being: Synthesis. Washington, DC: Island Press.

Manson, P. 2010. "Role of Ecosystem Function in Measurement of Economic Aspects of Ecosystem Services." Presentation at the 2010 ACES Conference, Phoenix, AZ. Available at: $\mathrm{http}: / /$ conference.ifas.ufl.edu/aces/agenda_Pres.html.

McCauley, D.J . 2006. “Selling Out on Nature.” Nature 443(7): 27-28.

Menzel, S. and J . Teng. 2009. "Ecosystem Services as a Stakeholder-Driven Concept for Conservation Sciences." Conservation Biology 24(3): 907-909.

Naeem, S., D.E. Bunker, A. Hector, M. Loreau, and C. Perrings, editors. 2009a. Biodiversity, Ecosystem Functioning, and Human Wellbeing: An Ecological and Economic Perspective." Oxford, UK: Oxford University Press.

. 2009b. "Can We Predict the Effects of Global Change on Biodiversity Loss and Ecosystem Functioning?" in Biodiversity, Ecosystem Functioning, and Human Wellbeing: An Ecological and Economic Perspective. Oxford, UK: Oxford University Press.

Norris, K., S.G. Potts, S.R. Mortimer. 2010. "Ecosystem Services and Food Production.” In Issues in Environmental Science and Technology, \#30 Ecosystem Services, edited by R.E. Heister and R. M. Harrison. Cambridge, UK: RSC Publishing.

ODUSD I\&E (Office of the Under Secretary of Defense, Installations and Environment). 2008. "Department of Defense Natural Infrastructure Asset Valuation Guide Volume 2" (Technical volume, draft.) Washington, D.C.: ODUSD I\&E.

Pitts, D. 2008. “Valuation Assessment of Ecosystems.” Public Works Technical Bulletin 200-2-58. Washington, D.C.: United States Army Corps of Engineers. 
Ranganathan, J . and Hazlewood, P. 2010. "Using Nature to Reach the Millennium Development Goals.” Washington, DC: World Resources Institute. Available at: http://www.wri.org/stories/2010/09/using-nature-reach-millennium-development-goals.

Rajvanshi, A., V.B. Mathur, and R. Slootweg. 2010. "Biodiversity in Environmental Impact Assessment." In Biodiversity in Environmental Assessment: Enhancing Ecosystem Services for Human Well-Being, edited by R. Slootweg, A. Rajvanshi, V.B. Mathur, and A. Kolhoff. Cambridge, UK: Cambridge University Press.

Rawlins, W. 2009. "Natural Infrastructure Management." Presentation at the 2009 Environmental, Energy and Sustainability Symposium held in Denver, Colorado. Available at: http://e2s2.ndia.org/pastmeetings/2009/tracks/Documents/8021.pdf.

Reid, W.V. 2006. “Nature: The Many Benefits of Ecosystem Services.” Nature 443(7): 749.

Ruhl, J .B., S.E. Kraft, and C. L. Lant. 2007. The Law and Policy of Ecosystem Services. Washington, DC: Island Press.

Ruhl, J .B. 2010. "Oceans and Ecosystem Services: Moving from Soft Policy to Hard Law to Apply." Presentation at the 2010 ACES conference, Phoenix, AZ. Available at: http://conference.ifas.ufl.edu/aces/agenda_Pres.html.

Slootweg, R., A. Rajvanshi, V.B. Mathur, and A. Kolhoff, editors. Biodiversity in Environmental Assessment: Enhancing Ecosystem Services for Human WellBeing, Cambridge, UK: Cambridge University Press.

Small, R.A. and D.J . Lewis. 2009. "Forest-land Conversion, Ecosystem Services, and Economic Issues for Policy: A Review." PNW-GTR-797. Portland, OR: United States Department of Agriculture, Forest Service, Pacific Northwest Research Station.

Solan, M., J . Godbold, A. Symstad, D.F.B. Flynn, D.E. Bunker. 2010. “BiodiversityEcosystem Function Research and Biodiversity Futures: Early Bird Catches the Worm or a Day Late and a Dollar Short?" In Biodiversity, Ecosystem Functioning, and Human Wellbeing: An Ecological and Economic Perspective, edited by S. Naeem, D.E. Bunker, A. Hector, M. Loreau, and C. Perrings. Oxford, UK: Oxford University Press.

Stahl J r., R., R. Gouguet, A. DeSantis, J. Liu, and M. Ammann. 2007. Prospective Environmental Restoration/ Restoration Up Front: A Concept for an IncentiveBased Program to Increase Restoration Planning and Implementation in the United States. Integrated Environmental Assessment and Management 4(1): 614.

Tallis, H., W. Yukuan, Z. Bo, F. Bin, Z. Wanze, C. Min, C. Tam, and G. Daily. 2010.Ecosystem Services and the Ecosystem Approach: The Natural Capital Project. Bulletin of the British Ecological Society (41)1: 10-13.

Thornes, J . 2010. “Atmospheric Services.” In Issues in Environmental Science and Technology, \#30 Ecosystem Services, edited by R.E. Heister and R. M. Harrison. Cambridge, UK: RSC Publishing. 
TNC (The Nature Conservancy). 2008. "Ecosystem Services and Environmental Management and Conservation on Military Lands, Workshop Outcomes." Washington, DC: Strategic Environmental Research and Development Program. Available at: http://workshops.serdp-estcp.org/ecosystems/outcomes.cfm.

UN Millennium Project. 2005. “Environment and Human Well-being: A Practical Strategy." Summary version of the report of the Task Force on Environmental Sustainability, New York, NY: The Earth Institute at Columbia University.

USAID (United States Agency for International Development). 2010. "Biodiversity Conservation and Forestry Programs Annual Report.” Washington, DC: USAID.

Waite, A. 2009. “ISR Natural Infrastructure.” FY2010 Centralized Training presentation, Washington, DC: Assistant Chief of Staff for Installation Management, Office of the Directorate - Reserve.

Watson, R.T. and A.H. Zakri (Co-Chairs Millennium Ecosystem Assessment Board). 2005. Living Beyond Our Means: Natural Assets and Human Well-Being, Statement from the Board." Washington, DC: Island Press.

WRI (World Resources Institute) in collaboration with United Nations Development Programme, United Nations Environment Programme, and World Bank. 2005. World Resources 2005: The Wealth of the Poor-Managing Ecosystems to Fight Poverty. Washington, DC: WRI.

. 2008a. World Resources 2008: Roots of Resilience, Growing the Wealth of the Poor. Washington, DC: WRI.

WRI (World Resources Institute) in collaboration with World Business Council for Sustainable Development and Meridian Institute. 2008b. The Corporate Ecosystem Services Review: Guidelines for Identifying Business Risks and Opportunities Arising from Ecosystem Change. Washington, DC: WRI.

\section{Website links (limited)}

A Community on Ecosystem Services (ACES) 2010 Conference http://conference.ifas.ufl.edu/ACES/

Millennium Ecosystem Assessment http://www.maweb.org/en/index.aspx

National Ecosystem Services Partnership http://nicholasinstitute.duke.edu/ecosystem/nesp

National Geophysical Data Center Ecosystem Informatics http://www.ngdc.noaa.gov/ecosys/ecosys.shtml

Office of Environmental Markets http://www.fs.fed.us/ecosystemservices/OEM/index.shtml

The Economics of Ecosystems and Biodiversity (TEEB) http://www.teebweb.org/ 
The Ecosystem Marketplace

http://www.ecosystemmarketplace.com/

The Ecosystem Services Project (Australia)

http://www.ecosystemservicesproject.org/index.htm

The Natural Capital Project

http://www.naturalcapitalproject.org/about.html

World Data Center for Biodiversity and Ecology

http://wdc.nbii.gov/ma/

World Resources Institute

http://www.wri.org/ecosystems/sustainable-business-and-markets

\section{Other resources}

BenDor, T.K. and M. W. Doyle. 2010 Planning for ecosystem service markets, J ournal of the American Planning Association 76 (1): 59- 72.

Chan, K.M.A., M.R.Shaw, D.R.Cameron, E.C.Underwood,and G.C.Daily. 2006.

“Conservation Planning for Ecosystem Services." PLoS Biology 4(11): e379 DOI: 10.1371/journal.pbio.0040379.

Holdran, J .P. 2008. "Science and Technology for Sustainable Well-Being." Science 319: 424- 435.

Naidoo, R., A. Balmford, R. Costanza, B. Fisher, R.E. Green, B. Lehner, T.R. Malcolm, and T.H. Ricketts. 2008. "Global Mapping of Ecosystem Services and Conservation Priorities.” Proceedings of the National Academy of Science 105(28): 9495-9500.

Ringold, P.L., J . Boyd , D. Landers, and M. Weber. 2009. "Report from the Workshop on Indicators of Final Ecosystem Services for Streams." EPA/ 600/ R-09/ 137, Washington, DC: United States Environmental Protection Agency, available at: http://epa.gov/ord/esrp/pdfs/IndicatorsFinalWorkshopReportEPA600R09137.pdf.

Ristino, L. 2010. “Conservation Easements in an Ecosystem Services Age.” Natural Resources \& Environment 24(3):56-59.

Sala, O.E., L.A. Meyerson, and C. Parmesan, editors. 2009. Biodiversity Change and Human Health: From Ecosystem Services to Spread of Disease. Washington, DC: Island Press.

Wilkinson, J.B., J.M. McElfish, R. Kihslinger J r., R. Bendick, and B.A. McKenney. 2009. "The Next Generation of Mitigation: Linking Current and Future Mitigation Programs with State Wildlife Action Plans and Other State and Regional Plans." Washington DC: Environmental Law Institute and The Nature Conservancy. 


\section{REPORT DOCUMENTATION PAGE}

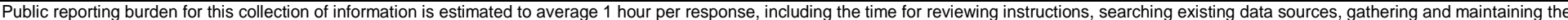

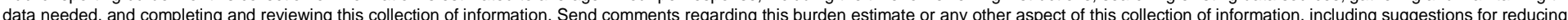

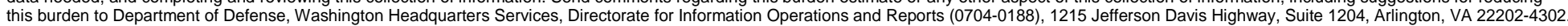

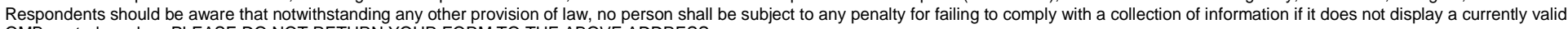
OMB control number. PLEASE DO NOT RETURN YOUR FORM TO THE ABOVE ADDRESS.
1. REPORT DATE (DD-MM-YYYY) 30-09-2011
2. REPORT TYPE FINAL

\section{TITLE AND SUBTITLE}

Relevance of Emerging Ecosystem Service Science and Policy to the United States

Department of Defense

\section{DATES COVERED (From - To)}

5a. CONTRACT NUMBER

No. W9132T-10-C-0045

5b. GRANT NUMBER

5c. PROGRAM ELEMENT

6. AUTHOR(S)

Elizabeth Keysar

\section{5d. PROJECT NUMBER}

5e. TASK NUMBER

5f. WORK UNIT NUMBER

9J 2017

7. PERFORMING ORGANIZATION NAME(S) AND ADDRESS(ES)

Concurrent Technologies Corporation

8. PERFORMING ORGANIZATION REPORT NUMBER

100 CTC Drive

Johnstown, PA 15904

\section{SPONSORING I MONITORING AGENCY NAME(S) AND ADDRESS(ES)}

Army Environmental Policy Institute 1550 Crystal Dr

Arlington VA 22202
US Army Engineer Research and Development Center (ERDC)

Construction Engineering Research Laboratory

(CERL)

PO Box 9005

Champaign, IL 61826-9005
10. SPONSOR/MONITOR'S ACRONYM(S)

AEPI; ERDC-CERL

\section{SPONSOR/MONITOR'S REPORT NUMBER(S) \\ ERDC/ CERL CR-11-1}

12. DISTRIBUTION I AVAILABILITY STATEMENT

Approved for public release; distribution is unlimited.

\section{SUPPLEMENTARY NOTES}

\section{ABSTRACT}

The concept of ecosystem services has been increasingly applied to ensure the benefits from ecosystems are incorporated into decision making. This idea supports sustainability goals by linking natural capital with financial capital. The concept of ecosystem services can assist the United States Department of Defense (DoD) in making natural resources decisions today for improved long-term outcomes. The concept also has strategic planning implications because the military's role continues to evolve along with international security concerns. This report summarizes the latest literature on ecosystem services in science and policy, to describe ways in which emerging applications of this concept may impact military planning and policy. The report's four sections provide an overview of the concept of ecosystem services and its recent adoption by major science and policy stakeholders; reviews of some recent applications of the concept; links of these applications to military activities; and recommendations and conclusions. The study concludes the DoD needs to (1) successfully engage with stakeholders on conservation issues; (2) use new tools and data sources in decision making; and (3) prepare for new regulatory requirements. The DoD should move forward with institutionalizing the concept of ecosystem services through additional research, engagement, training, and outreach.

\section{SUBJECT TERMS}

CASI, ecosystem services, ecosystem management, economic analysis, sustainability, training lands

\begin{tabular}{|c|c|c|c|c|c|}
\hline 16. SECURIT & IFICATION OF: & & 17. LIMITATION & 18. NUMBER & 19a. NAME OF RESPONSIBLE PERSON \\
\hline $\begin{array}{r}\text { a. REPORT } \\
\text { UU }\end{array}$ & $\begin{array}{c}\text { b. ABSTRACT } \\
\text { UU }\end{array}$ & $\begin{array}{c}\text { c. THIS PAGE } \\
\text { UU }\end{array}$ & UU & 42 & $\begin{array}{l}\text { 19b. TELEPHONE NUMBER } \\
\text { (include area code) }\end{array}$ \\
\hline
\end{tabular}

